\title{
Possible Effects of a Free School Meal on School Environment: The School Meal Intervention in Norway
}

\author{
Kristine E. Illøkken \\ Department of Nutrition and Public Health, University of Agder, Norway \\ Nina Cecilie Øverby \\ Department of Nutrition and Public Health, University of Agder, Norway \\ Berit Johannessen \\ Department of Health and Nursing Sciences, University of Agder, Norway \\ Frøydis Nordgård Vik \\ Department of Nutrition and Public Health, University of Agder, Norway
}

\begin{abstract}
Evidence suggests that a free school meal can improve children and adolescent diet, social environment, concentration, and school performance. This study aimed to investigate possible effects of a free, healthy school meal among students that usually eat packed meals on behavioral issues, inactiveness, self-efficacy, school enjoyment and classroom environment. A school meal according to the dietary guidelines was served to students in the intervention group $(n=55)$ for one year. A control group consumed packed meals as usual $(n=109)$. Students $(10-12$ years) responded to a questionnaire at baseline and after one year. We used linear regression analyses and did not find significant effects of a free school meal on behavioral issues $(\mathrm{B}=0.01, p 0.86)$, inactiveness $(\mathrm{B}=-0.05, p 0.51)$, self efficacy $(\mathrm{B}=-0.04, p 0.52)$, school enjoyment $(\mathrm{B}=0.11, p 0.19)$ or classroom environment $(\mathrm{B}=-0.07, p 0.26)$. Methodological limitations might explain our lack of findings.
\end{abstract}

Keywords: Free school meal, school lunch, behavior, inactiveness, self-efficacy, school enjoyment, Norway, intervention

\section{Background}

A healthy nutritious diet as an integrated element of a healthy lifestyle provides optimal conditions for brain development, cognition and learning (Naveed, Lakka, \& Haapala, 2020). In particular, a high intake of fish, fruit and vegetables is associated with improved academic achievement during childhood (Naveed et al., 2020). Healthy school meals are seen as important investments in children's wellbeing and for the future, as it provides an opportunity for social interaction and helps prepare them for the rest of the school day (Sarlio-Lähteenkorva \& Manninen, 2010). The school meal offers a break from the formal 
school day, and a setting where social bonds can strengthen, through a sense of commonality and through talking with and caring for each other (Fossgard, Wergedahl, Bjorkkjaer, \& Holthe, 2018; Neely, Walton, $\&$ Stephens, 2014). A healthy meal environment can also improve student alertness at school (Golley et al., 2010).

There are no universal free school meals in Norway, and less than $10 \%$ of schools from $1^{\text {st }}-10^{\text {th }}$ grade have local arrangements for parent-paid school meals (breakfast and lunch)(Federici et al., 2017). Most students in Norway (96\%) attend public schools (Statistics Norway, 2020). Public schools therefore constitute a setting where all children and adolescents regardless of social background and life circumstances, can be reached (Kairiene \& Sprindziunas, 2016). Meals eaten at school during lunchtime constitute $23-29 \%$ of students total dietary intake (TDI), whereas if both breakfast and lunch are provided at school, this may contribute to nearly $50 \%$ of their TDI (Colombo, Patterson, Elinder, \& Lindroos, 2020; Cullen \& Chen, 2017; Prynne et al., 2013; Sanigorski, Bell, Kremer, \& Swinburn, 2005).

Traditionally, Norwegian children and adolescents bring packed lunches from home. Like many other students from high income countries without provided school meals, parents/caretakers are responsible for providing school meals, resulting in varying nutritional quality (Evans, Cleghorn, Greenwood, \& Cade, 2010; Prynne et al., 2013; Sanigorski et al., 2005). In a systematic review, Mekonnen et al. (2020) showed that self-efficacy, food preferences, knowledge, availability and accessibility at home, food rules and parental modeling are important mediating factors for socio-economic differences in youths' diet. Thus, the home environment is important for children's dietary behavior. Furthermore, a more favorable dietary pattern is seen among youth with higher educated parents; they consume more fruit and vegetables, and less sugar-sweetened beverages and energy dense food (Desbouys, Méjean, De Henauw, \& Castetbon, 2020).

In Sweden, the national free school meal makes an important contribution to student diet with higher nutrient density compared to meals consumed outside school. This was particularly important for students with lower socio-economic status (SES) as the free meal at school compensated for a lower dietary quality at home (Colombo et al., 2020). Recently, Lundborg et al. (2021) documented that exposure to the Swedish school meal during school children's entire period in primary school had long-term positive effects on lifetime income, with greater effect among low SES households (Lundborg, Rooth, \& AlexPetersen, 2021).

In Norway, a study showed that serving a free school meal for one year increased students intake of healthy foods, particularly among students with lower socio-economic status (SES) and thereby suggested that free school meals may be an approach to reduce health inequalities (Vik, Van Lippevelde, \& Øverby, 2019). However, these social and cultural differences do not only impact student dietary habits. A Norwegian report (The Church City Mission, 2019) triggered a public debate in the media, as it revealed that there is a stigma and a social divide related to packed school meals. Young people living in poverty during childhood experienced the school meal situation as something they were ashamed over because they did not have a packed meal with them; or they had packed meals that negatively stood out compared to 'normal' packed meals (The Church City Mission, 2019). 
This corresponds to previous research suggesting that providing a free school meal only to students from disadvantaged families may generate stigma and segregation (Kairiene \& Sprindziunas, 2016; Yu, Lim, \& Kelly, 2019). As universal free school meals represent a great potential for benefits on several domains of childhood development, such as their social climate and well-being (Taylor, Garnett, Horton, \& Farineau, 2020), for improved diet (Cohen, Hecht, McLoughlin, Turner, \& Schwartz, 2021; Evans et al., 2010), academic performance (Cohen et al., 2021) and for reducing social inequalities (Lundborg et al., 2021; Vik, Van Lippevelde, et al., 2019), free school meals represent an important target in public health.

During one school year, students in a Norwegian $6^{\text {th }}$ grade were served a free healthy school meal in a project named 'The School Meal Project'. The primary outcome of the project was dietary behaviors at school reported elsewhere (Illøkken et al., 2017; Vik, Næss, Heslien, \& Øverby, 2019; Vik, Van Lippevelde, et al., 2019). Besides dietary behaviors, students in 'The School Meal Project' answered questions related to behavioral aspects of the school day such as behavioral issues, inactiveness in class, self-efficacy, school enjoyment and classroom environment. Thus, we wanted to investigate whether the free school meal had effects on behavioral issues, inactiveness, self-efficacy, school enjoyment and classroom environment as well, defined as school environment in the current study. Further if boys and girls, and students with higher or lower socio-economic status (SES), responded to the intervention in different ways.

The aim of this study was to investigate possible effects of a free, healthy school meal on reducing behavioral issues and inactiveness, increasing self-efficacy and school enjoyment, and improving classroom environment.

\section{Methods}

\section{The School Meal Project}

'The School Meal Project' was a non-randomized intervention conducted in two elementary schools in Norway. During one school year, Norwegian $6^{\text {th }}$ grade students aged 11 years old (the intervention group) were served a daily free healthy school meal at lunch time (cold meal with bread, healthy spread, fruit and vegetables) according to the Norwegian Dietary Guidelines, while a control group continued with packed meals as usual. The project was initially proposed by a local cook who prepared and served the meal. The research team at the University of Agder designed and carried out the research activities. A convenience sample consisting of one control group $(\mathrm{n}=109)$ and one intervention group $(\mathrm{n}=55)$ was therefore chosen to make the intervention feasible.

The project had a participation rate of $75 \%$ at baseline; participation rate in intervention group and control group was respectively $96 \%$ and $67 \%$ (Figure 1). Students in both groups answered a comprehensive pen and paper-based questionnaire at baseline (August 2014) and follow-up (June 2015). Consent to participate was gathered by active parental consent following principles from Wolfenden et al. (2009). The students were informed about the possibility to withdraw from the project. The project had few respondents lost to follow-up ( $n=3$ in each group), these were due to absence from school, withdrawal 
or moving to another school district (Figure 1). The design and methods have previously been described (Vik, Van Lippevelde, et al., 2019).

\section{Figure 1}

Flow chart of the enrollment process (Vik, Van Lippevelde, et al., 2019)

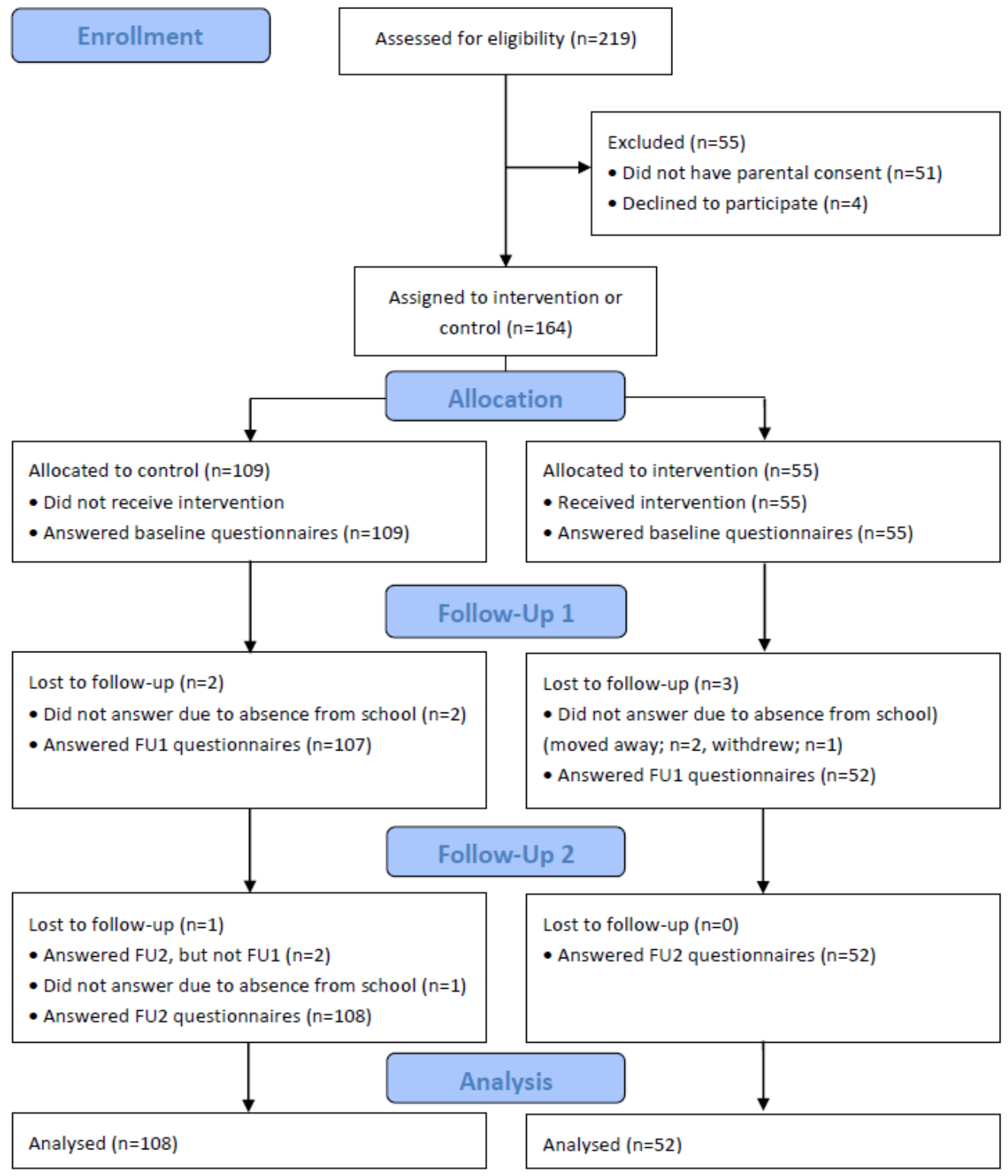

\section{Measures}

A likert-scale questionnaire was used to measure our school environment outcome variables: behavioral issues, inactiveness, self-efficacy, school enjoyment and classroom environment. Table 1 presents the survey questions in the questionnaire 


\section{Table 1}

Survey questions for school environment, main variables indicated in bold.

Behavioral issues

Do you make so much noise in class that the teachers yell at you?

Are you expelled from class because you make too much noise?

Does your teacher write down your name because of bad behavior?

Do you disturb the class to such an extent that other students in your class can't pay attention?

Inactiveness

Do you find it uncomfortable to speak up in class?

Do you raise your hand to answer questions in class? ${ }^{+}$

Do you feel shy in class?

How often does it happen that you haven't said anything in class for one day?

When I have to say something in class, I'm afraid that I will say something stupid

How often do you feel shy in meeting with people of the opposite gender?

Occasionally you do not raise your hand even though you know the answer, because it is

uncomfortable to speak up in class

School enjoyment

I like being at school

The school is interesting

I look forward to going to school

I like school activities

We do a lot of fun things at school

I wish I didn't have to go to school ${ }^{+}$

I do not like school activities ${ }^{+}$

I learn a lot at school

It is many things at school which I don't like ${ }^{\dagger}$

The teachers assist me when I need it

Self-efficacy

I can master the subjects that is taught in school this year

I can do even the most demanding work if I try

If I have enough time, I can do a good job with all my schoolwork

I can do almost any schoolwork if I don't give up

I can learn schoolwork although it is demanding

I'm sure that I can figure out how to do the most demanding work

Classroom environment

The students in my class enjoy being together

Most of my fellow students are kind and helpful with each other

My fellow students accept me as I am

When a classmate is upset, the others comfort him / her

'reversed item.

Each item had 5 response alternatives ranging from very often, often, sometimes, rarely, to never, except from self-efficacy (responses completely true, true, partly true, untrue and completely untrue) and classroom environment (responses always, often, sometimes, rarely, never). The questionnaire was pilottested prior to data collection, and parts of the questionnaire is used in previous research (Øverby \& Høigaard, 2012).

Sum- score variables were made for each outcome variable by summarizing the score from each question. Change variables for each outcome variable were made by subtracting follow-up score with baseline values to investigate possible change in the outcome variables.

Parental educational level was reported by parents in a separate questionnaire and used as proxy 
for SES. The scores for SES were dichotomized into lower or higher SES based on two items. First "what is your highest level of completed education" and second "what is your partner's highest level of completed education"? The response options were "primary school", "upper secondary school”, "3-4 years higher education and "5 or more years of higher education" (and "do not have a partner" for the second item).

Lower SES was identified as both parents (or one single parent) having completed primary school and upper secondary school, and higher SES with at least one parent completed higher education (Vik, Van Lippevelde, et al., 2019).

\section{Statistics}

The sum-scores for behavioral issues, inactiveness, self-efficacy, school enjoyment and classroom environment were all found reliable with respectively $\alpha=0.7,0.7,0.9,0.9$ and 0.8 Cronbach's alpha values, confirming internal consistency (Bland, 2015). Baseline- and descriptive characteristics are presented as proportion, mean and standard deviation (SD) or median and interquartile range (25\%-75\%) where appropriate. Preliminary analyses were performed to check that assumptions of normality, linearity, homoscedasticity, and multicollinearity were reasonably met. Linear regression was performed for each of the outcome variables to assess the effect of the free school meal (intervention/control group as the independent variable) on change in the outcome variables behavioral issues, inactiveness, school enjoyment, self-efficacy, and classroom environment. The regression analysis for each of the outcome variables are presented together in the complete regression model (Table 4). The model is adjusted for baseline measures (model 1), adding adjustment for gender in model 2 and adding gender and SES in model 3. Gender and SES were inserted as categorical variables ( $0=$ girl, $1=$ boy, SES:0=lower, $1=$ higher), while the change variable and baseline sum-score were indexed as continuous variables. Analyses were performed using IBM ${ }^{\circledR}$ SPSS $^{\circledR}$ Statistics 25.

\section{Results}

Out of 219 invited students, 164 (74\%) gave consent and participated at baseline. There were more boys in the intervention group compared to the control group ( $p 0.07$ ), and there were higher educated parents in the control group compared to the intervention group ( $p$ 0.23) (Table 2).

\section{Table 2}

Baseline demographic characteristics $(n=164)$

\begin{tabular}{|c|c|c|c|c|}
\hline Characteristics & All & $\begin{array}{l}\text { Intervention group } \\
(\mathrm{n}=55)\end{array}$ & $\begin{array}{l}\text { Control } \\
\text { Group }(n=109)\end{array}$ & $\begin{array}{l}\text { Group } \\
\text { comparison }\end{array}$ \\
\hline \multicolumn{5}{|l|}{ Gender, $n(\%)$} \\
\hline Boys & $85(52)$ & $34(62)$ & $51(47)$ & \\
\hline Girls & $79(48)$ & $21(38)$ & $58(53)$ & $p=0.007$ \\
\hline \multicolumn{5}{|l|}{ Age } \\
\hline Mean (SD) & $11.00(0.78)$ & $11.10(0.32)$ & $11.14(0.92)$ & $p=0.86$ \\
\hline \multicolumn{5}{|l|}{ SES, $n(\%)$} \\
\hline Lower & $53(39)$ & $21(46)$ & $32(35)$ & \\
\hline Higher & $63(41$ & $25(48)$ & $38(38)$ & $p=0.23$ \\
\hline
\end{tabular}


Pearson's chi square for gender and SES (socio-economic status). Independent sample t-test for age.

The intervention- and the control group were comparable with regards to behavioral issues, inactiveness in class, self-efficacy and classroom environment at baseline and follow-up (Table 3). There was a significant change in school enjoyment in favor of the intervention group at follow-up ( $p$ 0.04). This change was not adjusted for baseline (Table 3). Analysis adjusting for baseline presented in Table 4 did not show significant effects of free school meals on reduced behavioral issues or inactiveness, increased school enjoyment or self-efficacy or improved classroom environment. Overall, the analysis showed wide confidence intervals (Table 4). Furthermore, not related to intervention effect, analysis showed that girls reduced their inactiveness in class more than boys $(B=-0.21, p 0.02)$, and that there was a significant change in self-efficacy according to SES: students with higher educated parents increased their selfefficacy more compared to students with lower educated parents $(B=0.20, p<0.01)$.

Table 3 Descriptive scores for outcome variables as $m d(I Q R)$ and mean (SD) for change

\begin{tabular}{|c|c|c|c|c|c|c|c|c|c|}
\hline \multirow[t]{2}{*}{$\begin{array}{l}\text { Outcome } \\
\text { variables }\end{array}$} & \multicolumn{3}{|l|}{ Baseline } & \multicolumn{3}{|c|}{ Follow-up } & \multicolumn{3}{|c|}{ Change } \\
\hline & $\begin{array}{l}\text { Inter- } \\
\text { vention }\end{array}$ & Control & $\begin{array}{l}\text { p- } \\
\text { value } \\
*\end{array}$ & $\begin{array}{l}\text { Inter- } \\
\text { vention }\end{array}$ & Control & $\begin{array}{l}\text { p- } \\
\text { value } \\
*\end{array}$ & $\begin{array}{l}\text { Inter- } \\
\text { vention }\end{array}$ & Control & $\begin{array}{l}\text { p- } \\
\text { value** }\end{array}$ \\
\hline Behavior & $\begin{array}{l}5 \\
(4,7)\end{array}$ & $\begin{array}{l}5 \\
(4,6)\end{array}$ & 0.36 & $\begin{array}{l}5 \\
(4,7)\end{array}$ & $\begin{array}{l}5 \\
(4,6)\end{array}$ & 0.12 & $\begin{array}{l}-0.08 \\
(1.1)\end{array}$ & $\begin{array}{r}0.00 \\
(1.1)\end{array}$ & 0.68 \\
\hline $\begin{array}{l}\text { Inactivenes } \\
\mathrm{s}\end{array}$ & $\begin{array}{l}13 \\
(10,16)\end{array}$ & $\begin{array}{l}12 \\
(10,15)\end{array}$ & 0.83 & $\begin{array}{l}12 \\
(9,15)\end{array}$ & $\begin{array}{l}12 \\
(9,16)\end{array}$ & 0.74 & $\begin{array}{l}-0.29 \\
(4.3)\end{array}$ & $\begin{array}{r}0.22 \\
(4.0)\end{array}$ & 0.49 \\
\hline $\begin{array}{l}\text { Self- } \\
\text { efficacy }\end{array}$ & $\begin{array}{l}22 \\
(20,26)\end{array}$ & $\begin{array}{l}24 \\
(19,27)\end{array}$ & 0.11 & $\begin{array}{l}24 \\
(23,26)\end{array}$ & $\begin{array}{l}24 \\
(22,28)\end{array}$ & 0.33 & $\begin{array}{r}1.13 \\
(3.6)\end{array}$ & $\begin{array}{l}1.21 \\
(4.5)\end{array}$ & 0.92 \\
\hline $\begin{array}{l}\text { School } \\
\text { enjoyment }\end{array}$ & $\begin{array}{l}36 \\
(30,41)\end{array}$ & $\begin{array}{l}40 \\
(35,44)\end{array}$ & 0.27 & $\begin{array}{l}38 \\
(33,44)\end{array}$ & $\begin{array}{l}39 \\
(33,39)\end{array}$ & 0.08 & $\begin{array}{r}0.91 \\
(5.9)\end{array}$ & $\begin{array}{l}-1.28 \\
(5.7)\end{array}$ & 0.04 \\
\hline $\begin{array}{l}\text { Classroom } \\
\text { environme } \\
\mathrm{nt}\end{array}$ & $\begin{array}{l}17 \\
(16,19)\end{array}$ & $\begin{array}{l}18 \\
(16,19)\end{array}$ & 0.69 & $\begin{array}{l}17 \\
(16,18)\end{array}$ & $\begin{array}{l}18 \\
(16,19)\end{array}$ & 0.35 & $\begin{array}{l}-0.14 \\
(1.7)\end{array}$ & $\begin{array}{r}0.67 \\
(2.9)\end{array}$ & 0.58 \\
\hline
\end{tabular}

*Pearson's chi square

** Independent samples t-test 
JISTE, Vol. 25, No. 1, 2021

\section{Table 4}

Effect of a free school meal on change in behavioral issues, inactiveness, school enjoyment, self-efficacy and classroom environment using linear regression

\begin{tabular}{|c|c|c|c|c|c|c|}
\hline \multirow[t]{2}{*}{ Outcome variables } & \multicolumn{2}{|l|}{ Model 1} & \multicolumn{2}{|l|}{ Model 2} & \multicolumn{2}{|l|}{ Model 3} \\
\hline & Beta $(95 \% \mathrm{CI})$ & $\begin{array}{l}p \text { - } \\
\text { value }\end{array}$ & Beta $(95 \% \mathrm{CI})$ & $\begin{array}{l}p \text { - } \\
\text { value }\end{array}$ & Beta $(95 \% \mathrm{CI})$ & $\begin{array}{l}p \text { - } \\
\text { value }\end{array}$ \\
\hline \multicolumn{7}{|l|}{ Behavioral issues } \\
\hline Control/Intervention & $\begin{array}{l}0.01 \\
(-0.33-0.39)\end{array}$ & 0.86 & $\begin{array}{l}0.02 \\
(-0.33-0.41)\end{array}$ & 0.84 & $\begin{array}{l}0.01 \\
(-0.36-0.39)\end{array}$ & 0.94 \\
\hline Girls/boys & & & $\begin{array}{l}-0.04 \\
(-0.50-0.30)\end{array}$ & 0.63 & $\begin{array}{l}-0.04 \\
(-0.48-0.32)\end{array}$ & 0.69 \\
\hline Lower/Higher SES & & & & & $\begin{array}{l}-0.13 \\
(-0.65-0.08)\end{array}$ & 0.12 \\
\hline \multicolumn{7}{|l|}{ Inactiveness } \\
\hline Control/Intervention & $\begin{array}{l}-0.05 \\
(-1.87-0.93)\end{array}$ & 0.51 & $\begin{array}{l}-0.03 \\
(-1.61-1.17)\end{array}$ & 0.75 & $\begin{array}{l}-0.04 \\
(-1.75-1.10)\end{array}$ & 0.65 \\
\hline Girls/boys & & & $\begin{array}{l}-0.19 \\
(-2.95-(-0.21))\end{array}$ & 0.03 & $\begin{array}{l}-0.21 \\
(-3.14(-0.33)\end{array}$ & 0.02 \\
\hline Lower/Higher SES & & & & & $\begin{array}{l}-0.16 \\
(-2.73-0.08)\end{array}$ & 0.07 \\
\hline \multicolumn{7}{|l|}{ School enjoyment } \\
\hline Control/Intervention & $\begin{array}{l}0.11 \\
(-0.66-3.35)\end{array}$ & 0.19 & $\begin{array}{l}0.11 \\
(-0.65-3.39)\end{array}$ & 0.18 & $\begin{array}{l}0.11 \\
(-0.67-3.50)\end{array}$ & 0.18 \\
\hline Girls/Boys & & & $\begin{array}{l}-0.02 \\
(-2.16-1.64)\end{array}$ & 0.79 & $\begin{array}{l}-0.02 \\
(-2.20-1.71)\end{array}$ & 0.80 \\
\hline Lower/Higher SES & & & & & $\begin{array}{l}0.05 \\
(-1.32-2.60)\end{array}$ & 0.52 \\
\hline \multicolumn{7}{|l|}{ Self-efficacy } \\
\hline Control/Intervention & $\begin{array}{l}-0.04 \\
(-1.48-0.75)\end{array}$ & 0.52 & $\begin{array}{l}-0.05 \\
(-1.58-0.68)\end{array}$ & 0.43 & $\begin{array}{l}-0.03 \\
(-1.43-0.83)\end{array}$ & 0.60 \\
\hline Girls/Boys & & & $\begin{array}{l}0.07 \\
(-0.50-1.64)\end{array}$ & 0.29 & $\begin{array}{l}0.07 \\
(-0.49-1.66)\end{array}$ & 0.28 \\
\hline Lower/Higher SES & & & & & $\begin{array}{l}0.20 \\
(0.57-2.81)\end{array}$ & $<0.01$ \\
\hline \multicolumn{7}{|l|}{ Classroom environment } \\
\hline Control/Intervention & $\begin{array}{l}-0.07 \\
(-1.11-0.29)\end{array}$ & 0.26 & $\begin{array}{l}-0.08 \\
(-1.18-0.25)\end{array}$ & 0.20 & $\begin{array}{l}-0.08 \\
(-1.15-0.31)\end{array}$ & 0.26 \\
\hline Girls/Boys & & & $\begin{array}{l}0.07 \\
(-0.29-1.05)\end{array}$ & 0.26 & $\begin{array}{l}0.08 \\
(-0.29-1.09)\end{array}$ & 0.25 \\
\hline Lower/Higher SES & & & & & $\begin{array}{l}0.09 \\
(-0.20-1.23)\end{array}$ & 0.16 \\
\hline
\end{tabular}

Significant $p$-values indicated in bold. Dependent variable: Outcome variable. Model 1: Adjusted for baseline. Model 2: Adjusted for baseline and gender. Model 3: Adjusted for baseline, gender, and SES.

\section{Discussion}

This study did not demonstrate that a free healthy school meal for one year significantly reduced behavioral issues or inactiveness, increased school enjoyment or self-efficacy, or improved classroom 
environment.

Previous research has documented that healthy free school meals following nutritional guidelines can have a positive impact on several aspects in childhood and adolescence (Cohen et al., 2021). These include for instance social benefits, improved social climate, and making students more ready to learn (Taylor et al., 2020). Furthermore, previous research has demonstrated that a free school meal can improve satisfaction with schoolwork (Ask et al., 2010). Benn \& Carlsson (2014) showed how a free school meal can be beneficial for concentration and less disturbing noise in class. Berggren et al., (2017) explored how school meals can operate as a positive influence on children and adolescent wellbeing, concentration in school activities and their mood. Moreover, cross-sectional studies have shown an association between sub-optimal energy-dense diets high in sugar and behavior- and mental health problems (Lien, Lien, Heyerdahl, Thoresen, \& Bjertness, 2006; Oellingrath, Svendsen, \& Hestetun, 2014; Øverby \& Høigaard, 2012). However, Sorensen et al. (2015) showed inconsistent findings when investigating effect of free school meals on concentration and school performance, with improved reading performance but also increased inattention and impulsivity. The researchers relate these findings to methodological issues (Sorensen et al., 2015). Given our results as well, this indicates that evaluating free school meals is a complex issue. The lack of effects in the present study could therefore be due to methodological issues. More research is needed with improved study design and methods, as well as a larger study sample.

Given the wide Confidence Intervals we detected in our analyses, the study may be underpowered (Bland, 2015). In our case, this increases the risk of uncertain estimates and thus of the results being false negative. With 55 students in the intervention group, it is likely that we have a too small, and imbalanced (for gender and SES) sample size to show that a difference might exist (Bland, 2015). Furthermore, lack of randomization, as well as using self-reported unvalidated measurement tools and the narrow age-range in our sample limits the representativeness and generalizability of the results.

Significant changes as we found in our analysis for inactiveness between girls and boys, and for self-efficacy between lower and higher parental education status, may indicate that there are different things going on during the school year that we were not able to control for, regardless of receiving free healthy school meals. 'The School Meal Project', as this current study was a part of, has previously shown effective in promoting a healthy diet and reducing social health inequalities (Illøkken et al., 2017; Vik, Van Lippevelde, et al., 2019).

The lack of results that a free school meal might influence the school environment might be due to the survey questionnaire being unsuitable for measuring school environments. Therefore, rigorous interventions with a large study sample using a cluster randomized control design and validated measurement tools and a focus on increased understanding through qualitative measures are needed to explore the possible impact of free, healthy school meals on school environment. The long intervention period and high participation rates represents strengths of this study.

Although we did not find significant effects in our current study, others have, as mentioned earlier, showed that free school meals are beneficial for several domains of childhood development. A recent systematic review conducted by Cohen et al. (2021) documented that most studies investigating universal 
free school meals at lunch time following nutritional standards can promote a healthy diet, food security and academic performance. Further, as a healthy lifestyle with a healthy diet is associated with optimal learning (Naveed et al., 2020), we argue that school meals are of importance in an educational setting, for teachers and in teacher education as well.

However, Benn \& Carlsson (2014) illustrated a potential gap on the view of school meals in their research: they showed that a free school meal can function as a pedagogical platform where children can practice social skills and learn about food, while some teachers viewed school meals as relating to school health policy rather than education and learning (Benn \& Carlsson, 2014). Additionally, free school meals can be harmful by creating stigma if not offered as a universal free meal (Kairiene \& Sprindziunas, 2016; Yu et al., 2019) and organizational factors such as lack of time, noise, standing in line, and having limited offer of food choice can influence uptake of free school meals and the dining experience (Day, Sahota, Christian, \& Cocks, 2015; Sahota, Woodward, Molinari, \& Pike, 2014).

It may also be argued that school meals are not necessarily better than a packed lunch from home. A nutritious packed lunch with fruit and vegetables may for instance be a better choice than a free school meal of low quality. Free school meals may also be expensive for the municipalities and introduce logistics that may be challenging for schools that are not built for this purpose. We therefore suggest that future school meal programs and research should consider the limitations with our current study, focus on teacher involvement, implement policy for nutritional guidelines, consider universal free school meals, and further explore best possible local solutions for serving varied types of food and for reducing organizational barriers.

\section{Conclusion}

Serving of healthy, free school meals at lunchtime did not reduce behavioral issues or inactiveness in class, increased school enjoyment or self-efficacy, neither did it improve classroom environment in this study. Methodological issues might explain the lack of findings in our study. We encourage further research to enhance the understanding of universal free healthy school meals among different age groups, with a larger study sample, and with study designs involving perspectives of school children, family, staff, and policymakers.

\section{References}

Ask, A. S., Hernes, S., Aarek, I., Vik, F., Brodahl, C., \& Haugen, M. (2010). Serving of free school lunch to secondary-school pupils - a pilot study with health implications. Public Health Nutrition, 13(2), 238-244. doi:http://dx.doi.org/10.1017/S1368980009990772

Benn, J., \& Carlsson, M. (2014). Learning through school meals? Appetite, 78, 23-31. doi:https://doi.org/10.1016/j.appet.2014.03.008

Berggren, L., Talvia, S., Fossgard, E., Björk Arnfjörð, U., Hörnell, A., Ólafsdóttir, A. S., Olsson, C. (2017). Nordic children's conceptualizations of healthy eating in relation to school lunch. Health 
Education, 117(2), 130-147. doi:10.1108/HE-05-2016-0022

Bland, M. (2015). An introduction to medical statistics United Kingdom: Oxford University Press

Cohen, J. F. W., Hecht, A. A., McLoughlin, G. M., Turner, L., \& Schwartz, M. B. (2021). Universal school meals and associations with student participation, attendance, academic performance, diet quality, food security, and body mass index: A systematic review. Nutrients, 13(3). doi:10.3390/nu13030911

Colombo, P. E., Patterson, E., Elinder, L. S., \& Lindroos, A. K. (2020). The importance of school lunches to the overall dietary intake of children in Sweden: a nationally representative study. Public Health Nutrition, 1-11. doi:10.1017/S1368980020000099

Cullen, K. W., \& Chen, T.-A. (2017). The contribution of the USDA school breakfast and lunch program meals to student daily dietary intake. Preventive Medicine Reports, 5, 82-85. doi:https://doi.org/10.1016/j.pmedr.2016.11.016

Desbouys, L., Méjean, C., De Henauw, S., \& Castetbon, K. (2020). Socio-economic and cultural disparities in diet among adolescents and young adults: a systematic review. Public health nutrition, 23(5), 843-860. doi:10.1017/S1368980019002362

Evans, C. E. L., Cleghorn, C. L., Greenwood, D. C., \& Cade, J. E. (2010). A comparison of British school meals and packed lunches from 1990 to 2007: meta-analysis by lunch type. British Journal of Nutrition, 104(4), 474-487. doi:10.1017/S0007114510001601

Federici, R. A., Gjerustad, C., Vaagland, K., Larsen, E. H., Rønsen, E., \& Hovdhaugen, E. (2017). Norwegian report: Questions to schools in Norway spring 2017 [Spфrsmål til Skole-Norge våren 2017]. Retrieved from https://nifu.brage.unit.no/nifu-xmlui/handle/11250/2447569?localeattribute $=$ en

Fossgard, E., Wergedahl, H., Bjorkkjaer, T., \& Holthe, A. (2018). School lunch-children's space or teachers' governmentality? International Journal of Consumer Studies, 218-226. doi:http://dx.doi.org/10.1111/ijcs.12501

Golley, R., Baines, E., Bassett, P., Wood, L., Pearce, J., \& Nelson, M. (2010). School lunch and learning behaviour in primary schools: an intervention study. European Journal of Clinical Nutrition, 64(11), 1280-1288. doi:10.1038/ejcn.2010.150

Illøkken, K. E., Bere, E., Øverby, N. C., Høiland, R., Petersson, K. O., \& Vik, F. N. (2017). Intervention study on school meal habits in Norwegian 10-12-year-old children. Scandinavian journal of public health, 45(5), 485-491. doi:10.1177/1403494817704108

Kairiene, B., \& Sprindziunas, A. (2016). Social equality as groundwork for sustainable schooling: The free lunch issue. Journal of Teacher Education for Sustainability, 18(1), 127-139. doi:10.1515/jtes2016-0010

Lien, L., Lien, N., Heyerdahl, S., Thoresen, M., \& Bjertness, E. (2006). Consumption of soft drinks and hyperactivity, mental distress, and conduct problems among adolescents in Oslo, Norway. American Journal of Public Health, 96(10), 1815-1820. doi:10.2105/AJPH.2004.059477

Lundborg, P., Rooth, D.-O., \& Alex-Petersen, J. (2021). Long-term effects of childhood nutrition: 
Evidence from a school lunch reform. The Review of Economic Studies. doi:10.1093/restud/rdab028

Mekonnen, T., Havdal, H. H., Lien, N., O'Halloran, S. A., Arah, O. A., Papadopoulou, E., \& Gebremariam, M. K. (2020). Mediators of socioeconomic inequalities in dietary behaviours among youth: A systematic review. Obesity Reviews, 21:e13016. doi:10.1111/obr.13016

Naveed, S., Lakka, T., \& Haapala, A. E. (2020). An overview on the associations between health behaviors and brain health in children and adolescents with special reference to diet quality. International Journal of Environmental Research and Public Health, 17(3). doi:10.3390/ijerph17030953

Neely, E., Walton, M., \& Stephens, C. (2014). Young people's food practices and social relationships. A thematic synthesis. Appetite, 82, 50-60. doi:https://doi.org/10.1016/j.appet.2014.07.005

Oellingrath, I. M., Svendsen, M. V., \& Hestetun, I. (2014). Eating patterns and mental health problems in early adolescence - a cross-sectional study of 12-13-year-old Norwegian schoolchildren. Public Health Nutrition, 17(11), 2554-2562. doi:10.1017/S1368980013002747

Prynne, C. J., Handford, C., Dunn, V., Bamber, D., Goodyer, I. M., \& Stephen, A. M. (2013). The quality of midday meals eaten at school by adolescents; school lunches compared with packed lunches and their contribution to total energy and nutrient intakes. Public health nutrition, 16(6), 11181125. doi:http://dx.doi.org/10.1017/S1368980011002205

Sanigorski, A. M., Bell, A. C., Kremer, P. J., \& Swinburn, B. A. (2005). Lunchbox contents of Australian school children: room for improvement. European Journal of Clinical Nutrition, 59(11), 13101316. doi:10.1038/sj.ejcn. 1602244

Sarlio-Lähteenkorva, S., \& Manninen, M. (2010). School meals and nutrition education in Finland. Nutrition Bulletin, 35(2), 172-174. doi:10.1111/j.1467-3010.2010.01820.x

Sorensen, L. B., Dyssegaard, C. B., Damsgaard, C. T., Petersen, R. A., Dalskov, S. M., Hjorth, M. F., . . Egelund, N. (2015). The effects of Nordic school meals on concentration and school performance in 8- to 11-year-old children in the OPUS school meal study: A cluster-randomised, controlled, cross-over trial. British Journal of Nutrition, 113(8), 1280-1291. doi:http://dx.doi.org/10.1017/S0007114515000033

Statistics Norway. (2020). Pupils in primary and lower secondary school [internet]. Retrieved from https://www.ssb.no/en/utdanning/statistikker/utgrs

Taylor, J., Garnett, B., Horton, M. A., \& Farineau, G. (2020). Universal free school meal programs in Vermont show multi-domain benefits. Journal of Hunger \& Environmental Nutrition, 1-14. doi:10.1080/19320248.2020.1727807

The Church City Mission. (2019). Norwegian report: Talk about povery [snakk om fattigdom]. Retrieved from https://kommunikasjon.ntb.no/data/attachments/00634/ddc295c8-10a7-4a88-a53d60577110c907.pdf.

Vik, F. N., Næss, I. K., Heslien, K. E. P., \& Øverby, N. C. (2019). Possible effects of a free, healthy school meal on overall meal frequency among 10-12-year-olds in Norway: The school meal project. BMC Research Notes, 12(1), 382. doi:10.1186/s13104-019-4418-6 
Vik, F. N., Van Lippevelde, W., \& Øverby, N. C. (2019). Free school meals as an approach to reduce health inequalities among 10-12- year-old Norwegian children. BMC Public Health, 19(1), N.PAG-N.PAG. doi:10.1186/s12889-019-7286-Z

Wolfenden, L., Kypri, K., Freund, M., \& Hodder, R. (2009). Obtaining active parental consent for schoolbased research: a guide for researchers. Australian and New Zealand Journal of Public Health, 33(3), 270-275. doi:https://doi.org/10.1111/j.1753-6405.2009.00387.x

Yu, B., Lim, H., \& Kelly, S. (2019). Does receiving a school free lunch lead to a stigma effect? Evidence from a longitudinal analysis in South Korea. Social Psychology of Education, 22(2), 291-319. doi:10.1007/s11218-019-09485-7

Øverby, N., \& Høigaard, R. (2012). Diet and behavioral problems at school in Norwegian adolescents. Food \& Nutrition Research, 56(1), 17231. doi:10.3402/fnr.v56i0.17231

\section{Authors}

Kristine E. Illøkken is a PhD candidate in Health and Sport Sciences. The impact of diet, and particularly school meals, for learning among schoolchildren and adolescents are central in her research.

Nina Cecilie Øverby is a professor in nutritional epidemiology and is the leader of the Priority Research Centre on Lifecourse Nutrition at the University of Agder.

Berit Johannesen is an associate professor in Health and Nursing Sciences focusing on medical sciences, health promotion in a family perspective and interaction between animals and humans.

Frøydis Nordgård Vik is a professor in Public Health Nutrition focusing on diet and nutrition among children and adolescents in relation to health, especially school meals in a Nordic setting. 